\title{
Correction to: Factors associated with death in confirmed cases of COVID-19 in the state of Rio de Janeiro
}

Marcella Cini Oliveira" ${ }^{*}$, Tatiana de Araujo Eleuterio ${ }^{2,3}$, Allan Bruno de Andrade Corrêa ${ }^{4}$,

Lucas Dalsenter Romano da Silva ${ }^{5}$, Renata Coelho Rodrigues ${ }^{1}$, Bruna Andrade de Oliveira ${ }^{1}$, Marlos Melo Martins ${ }^{6}$, Carlos Eduardo Raymundo ${ }^{2}$ and Roberto de Andrade Medronho ${ }^{2}$

Correction to: BMC Infect Dis 21, 687 (2021)

https://doi.org/10.1186/s12879-021-06384-1

Following publication of the original article [1], the authors identified an error in the article title.

The incorrect title is:

Fatores associados ao óbito em casos confirmados de COVID-19 no estado do Rio de JaneiroThe

The correct title is:

Factors associated with death in confirmed cases of COVID-19 in the state of Rio de Janeiro

The original article [1] has been corrected.

\begin{abstract}
Author details
${ }^{1}$ Faculdade de Medicina, Universidade Federal do Rio de Janeiro, Rio de Janeiro, Brazil. ${ }^{2}$ Instituto de Estudos em Saúde Pública / Faculdade de Medicina, Universidade Federal do Rio de Janeiro, Rio de Janeiro, Brazil. ${ }^{3}$ Faculdade de Enfermagem, Universidade do Estado do Rio de Janeiro, Rio de Janeiro, Brazil. ${ }^{4}$ Instituto de Física, Universidade Federal do Rio de Janeiro, Rio de Janeiro, Brazil. ${ }^{5}$ Departamento de Medicina Preventiva, Instituto de Estudos em Saúde Pública / Faculdade de Medicina, Universidade Federal do Rio de Janeiro, Rio de Janeiro, Brazil. ${ }^{6}$ Department of Child Neurology, Martagão Gesteira Institute of Childcare and Pediatrics, Federal University of Rio de Janeiro, Rio de Janeiro, Brazil.
\end{abstract}

Published online: 02 August 2021

\section{Reference}

1. Oliveira C, et al. Factors associated with death in confirmed cases of COVID19 in the state of Rio de Janeiro. BMC Infect Dis. 2021;21:687. https://doi. org/10.1186/s12879-021-06384-1.

The original article can be found online at https://doi.org/10.1186/s12879021-06384-1.

* Correspondence: cini.marcella@gmail.com

${ }^{1}$ Faculdade de Medicina, Universidade Federal do Rio de Janeiro, Rio de Janeiro, Brazil

Full list of author information is available at the end of the article

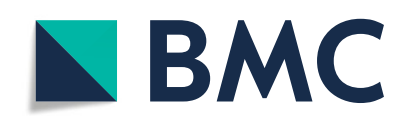

() The Author(s). 2021 Open Access This article is licensed under a Creative Commons Attribution 4.0 International License, which permits use, sharing, adaptation, distribution and reproduction in any medium or format, as long as you give appropriate credit to the original author(s) and the source, provide a link to the Creative Commons licence, and indicate if changes were made. The images or other third party material in this article are included in the article's Creative Commons licence, unless indicated otherwise in a credit line to the material. If material is not included in the article's Creative Commons licence and your intended use is not permitted by statutory regulation or exceeds the permitted use, you will need to obtain permission directly from the copyright holder. To view a copy of this licence, visit http://creativecommons.org/licenses/by/4.0/. The Creative Commons Public Domain Dedication waiver (http://creativecommons.org/publicdomain/zero/1.0/) applies to the data made available in this article, unless otherwise stated in a credit line to the data. 